\section{特別棓 演}

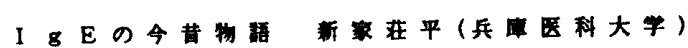
The history of studies on inunogloblin E. SHINkA, $s$.

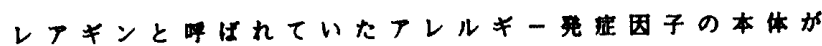
切めて明らかにされ、I $8 \mathrm{E}$ 命名されたのは1860

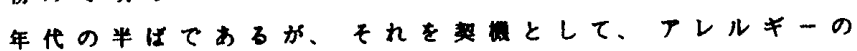

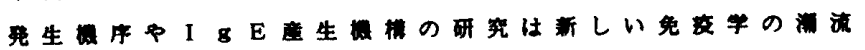

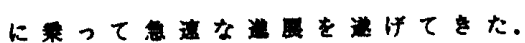

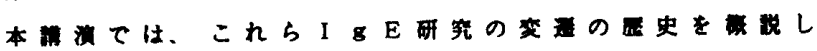

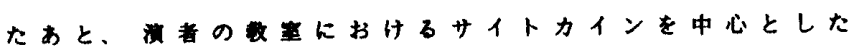

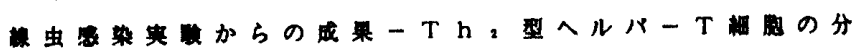

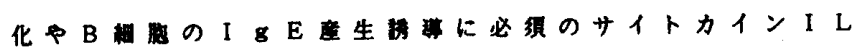

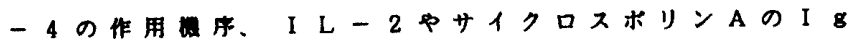

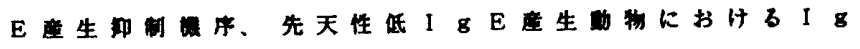

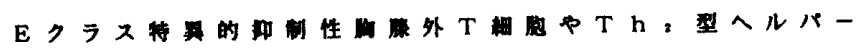

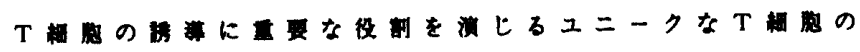
存在などに网する新しい知見一を眧介しながら、昨今の

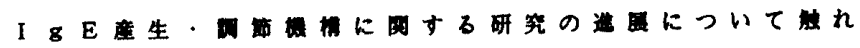
てみたい。

2 能登半典のマタ二刺症とマダ二蝶介性疾意に䦕

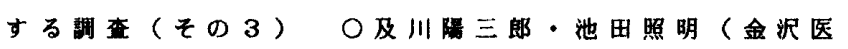

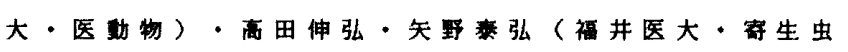
Epidemiologycal surveys of human tick bites and tick-born diseases in the Noto Peninsula (3).

0 ikawa $r .$, Ikeda $T$., Takada N. and Yano $r$.

演者らは1993年より能登半島でマダ二に閶する基磷調 查老行ってきた。マタ二の採策地域として本年新たに钵 伏山、別所岳および宝達山を加え、採菜されたマダ二稳

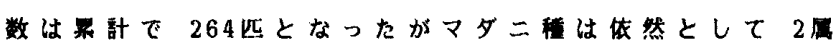
4 校少なかった。今回採集したマタ二20匹のBSK培地 による培盖では、别所岳で探策したヤマトマタ二雄成虫 より血清学的にBorrelia japonica と思われる1株分

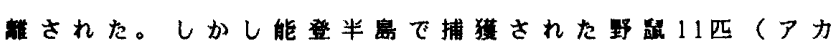
ネズミの耳介の培䔋では、ホレリアは分龍できなっ た。またB. japonica H014株を用いた|P法でも野或の血 清抗体洒法11例全例で低加つた ( $880>)$ 。一方、 Ricke : ttsia japonica 贯木株を用いた।P法では82\%(9例) の 野鼠加高い抗体值 $(x 2,560<)$ を示し、更にErancisella tularensis Schu株を用いたMA法では $9 \%(1$ 例) 加 $\times 10$ (情性)を示した。

\section{一般請演}

1 市内公回政に戈ける夕二相口吉田永祥・

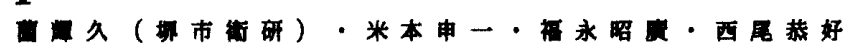
(大役市大. 医. 生物研) The ite fauna in the sandpits of public parks in sakai city,japan. H. YOSHIDA, T. SONO,S.YONEMOTO, A.FUKUNAGA Y.NISHIO

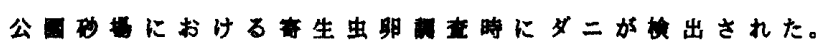
その实觉を明らかにするため、增市内の公日16ク所の称

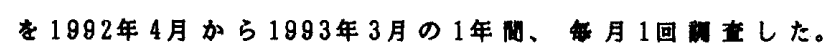

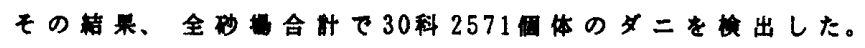
半数以上の月、列で出されたッブタ二出、コシボ

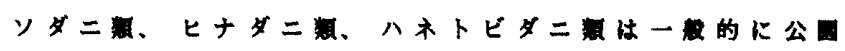

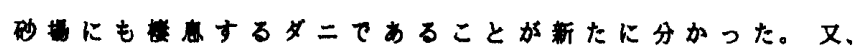

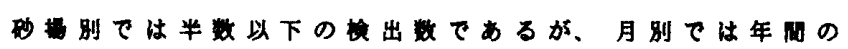

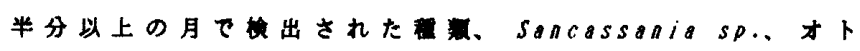
ヒメタ二

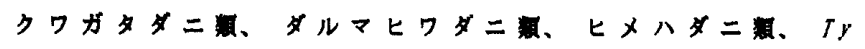

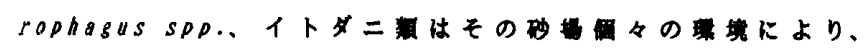
權虫可狏なダ二であると考える。

コミコナダは政508から1588㑲体出されアレルゲン

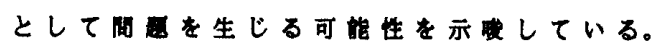

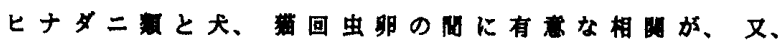

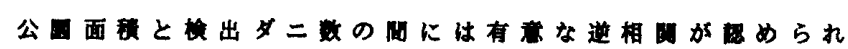
た。

3 外耳道マダ二寄生例○初鹿了（川渏

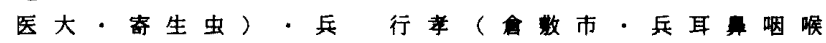
科医院) A human case of ear canal infestation ith a hard tick found in okayama Prefecture R. Hatsushika \& Y. Ho

患者は會数市德芳在住の主媂(45藏)。1995年 7 月 8 日、患者は左耳閉感亡左聴賞異常を訴えて 兵耳咽喉科医院を訪れた。恚者仙同年 6 月末頃 に左耳閉感を自觉したが放曼し、来院前日に自身 で耳授除した際に黒褐色の耳漏を認めた。耳镜端 查所見では、左饮骨部外耳道後下方に黑楬色を呈 した球状の異物が存在し、耳垍鴾に上りこの異物

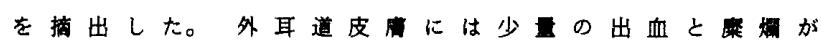
認めら扎たが、冒部外耳道および鼓膜には異常を 認めなかった。摘出した異物は直径約 $8 \mathrm{~mm}$ で、4 対の歩脚と 1 対の気門板を有し、マダ=の1個体 と思われた。マダ二は10\%【0日液で薏滞後、封入 標本としてその形慜を精查した結果、口下片. 触 肢・各步脚基節の棘・気門板などの特改らつタ トゲチマダ=( H. 1 O ngicornjs)の雌成虫と同定さ れた。マダ二摘出により患者の聴力は回復し、、

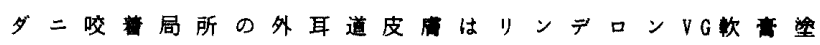
布によって約 2 週間後に完治した。現在まで発㲎 ・発疮などの全身症状は出現していない。恵者は、 铜い犬を連れてょく山道を散策している。本症例 は、岡山累におけるマダ二刺症の第2 2 例目である。 